\title{
Mucolipidosis II: correlation between radiological features and histopathology of the bones
}

\author{
U.E.Pazzaglia ${ }^{1}$, G. Beluffi ${ }^{3}$, J.B.Campbell ${ }^{4}$, E. Bianchi ${ }^{2}$, N.Colavita ${ }^{5}$, F. Diard ${ }^{6}$, P. Gugliantini ${ }^{7}$, U. Hirche $^{8}$, \\ K. Kozlowski ${ }^{9}$, A. Marchi ${ }^{2}$, V. Nayanar ${ }^{10}$ and G. Pagani ${ }^{11}$ \\ ${ }^{1}$ Clinica Ortopedica, ${ }^{2}$ Clinica Pediatrica, Università di Pavia, and \\ ${ }^{3}$ Servizio di Radiodiagnostica, IRCCS Policlinico S. Matteo, Pavia, Italy, ${ }^{4}$ Children's Hospital, Denver, Colorado, USA, \\ ${ }^{5}$ Istituto di Radiologia, Università Cattolica Sacro Cuore, Roma, Italy, ${ }^{6}$ Hopital des Enfants, Bordeaux, France, \\ ${ }^{7}$ Servizio di Radiologia, Ospedale Pediatrico Bambino Gesù, Roma, Italy, ${ }^{8}$ Kinderkrankenhaus Sankt Nikolaus, Ravensburg, FRG \\ ${ }^{9}$ Royal Alexandra Hospital for Children, and ${ }^{10}$ Prince of Wales Hospital, Sydney, Australia \\ ${ }^{11}$ Divisione di Pediatria, Servizio di Neonatologia, Ospedale S. Anna, Como, Italy
}

\begin{abstract}
Twelve cases of Mucolipidosis II (I-cell disease) with a wide range of severity of skeletal involvement were studied. Pathological findings in two cases provided helpful information in understanding the radiographic features of dysostosis multiplex. Inhibition of the growth plate cartilage calcification and rickets-like lesions were observed in the metaphyses. Enhanced subperiosteal remodelling and paratrabecular fibrosis were also evident in the diaphyses. High levels of parathormone were found in one case. This finding supports the hypothesis that bone lesions may be secondary, at least in part, to damage in such viscera as the kidney and/or the liver and that they are mediated by vitamin $D$ and parathormone.
\end{abstract}

The skeletal findings in the mucolipidoses and the mucopolysaccharidoses have been considered nonspecific and are therefore usually lumped together under the term "dysostosis multiplex" $[3-5,11$, 18-20]. Mucolipidosis II, or I-cell disease, may be distinguished from other storage diseases based on the age at which radiographic abnormalities are discovered and the occurrence of specific signs $[9,14$, 17].

We have collected twelve cases of I-cell disease with the aim of evaluating the variable radiographic features of the disorder and correlating these features with available histo-pathological material. To our knowledge, no attempt has hitherto been made to conduct such a radiologic-pathologic correlation. Our analysis has confirmed the variable but highly suggestive radiographic features encountered at vari- ous ages. Thorough histo-pathologic evaluation in two cases provided provocative clues to the interpretation of the radiographic features of dysostosis multiplex.

\section{Case material}

Twelve babies in twelve families from Australia (one), France (one), Germany (two), Italy (five) and USA (three) were studied. In two families there was consanguinity between parents and in three there were miscarriages or babies who died soon after birth.
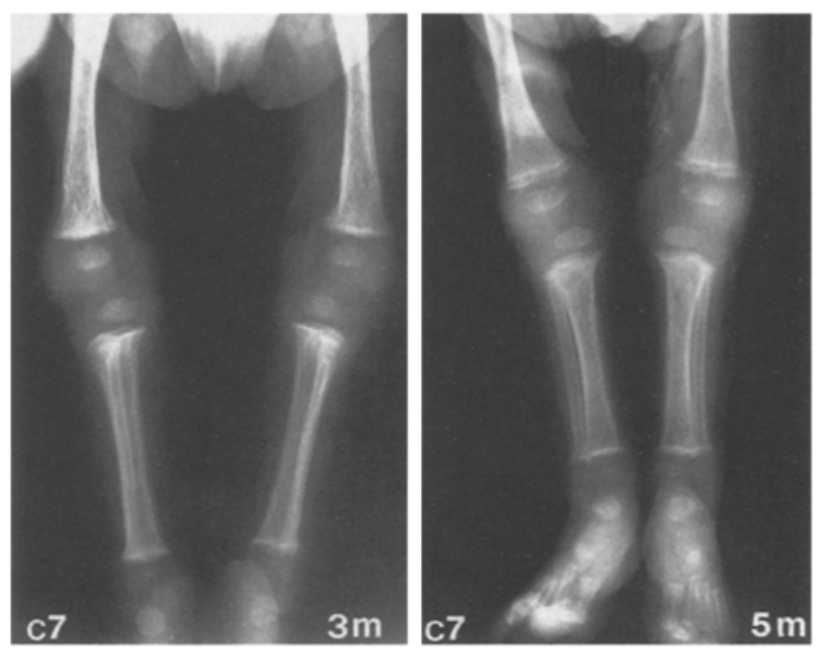

Fig. 1. Case 7. Generalised osteopenia and coarse fibrillar texture of the bones. The metaphyses are enlarged; slant is well evident in both proximal tibiae and cupping in the distal fibulae at 5 months. A radiotransparent, transverse band appeared at 5 months in the distal femoral and proximal tibial metaphyses. Double outline of the tibial shafts resembling periosteal apposition (cloaking) and stippling of tarsal bones 
Table 1. I-cell disease - clinical data

\begin{tabular}{|c|c|c|c|c|c|c|}
\hline & $\begin{array}{l}\text { 1. NN } \\
\text { (Roma) }\end{array}$ & $\begin{array}{l}\text { 2. BS } \\
\text { (Roma) }\end{array}$ & $\begin{array}{l}\text { 3. CF } \\
\text { (Como) }\end{array}$ & $\begin{array}{l}\text { 4. NV } \\
\text { (Ravensburg) }\end{array}$ & $\begin{array}{l}\text { 5. CF } \\
\text { (Sidney) }\end{array}$ & $\begin{array}{l}\text { 6.SZ } \\
\text { (Ravensburg) }\end{array}$ \\
\hline Sex & $\mathbf{F}$ & M & $\mathbf{M}$ & $\mathrm{M}$ & $\mathrm{F}$ & $\mathbf{F}$ \\
\hline $\begin{array}{l}\text { Age of } \\
\text { diagnosis }\end{array}$ & birth & birth & birth & birth & birth & birth \\
\hline $\begin{array}{l}\text { Family } \\
\text { history }\end{array}$ & $\begin{array}{l}1 \text { sibs ML2 } \\
\text { dead } 6 \mathrm{~m}\end{array}$ & $\begin{array}{l}3 \text { previous } \\
\text { miscarriages } \\
1 \text { brother ML2 }\end{array}$ & $\begin{array}{l}\text { parents } 4 \text { th } \\
\text { cousins }\end{array}$ & ns & $\begin{array}{l}1 \text { sib ML2 } \\
\text { dead birth }\end{array}$ & ns \\
\hline Age of death & If & $4 \mathrm{~m}$ & $4 \mathrm{~m}$ & $1 d$ & $5 d$ & If \\
\hline Birth weight & $1950 \mathrm{~g}$ & $2750 \mathrm{~g}$ & $2030 \mathrm{~g}$ & $2720 \mathrm{~g}$ & $2065 \mathrm{~g}$ & $2050 \mathrm{~g}$ \\
\hline Birth length & $40 \mathrm{~cm}$ & 0 & 0 & $49 \mathrm{~cm}$ & $43 \mathrm{~cm}$ & 0 \\
\hline Caryogram & 0 & $46, X Y$ & $46, X Y$ & 0 & $46, \mathrm{XX}$ & $46, \mathrm{XX}$ \\
\hline $\begin{array}{l}\text { Laboratory } \\
\text { tests }\end{array}$ & 0 & $\begin{array}{l}\text { serum hydrolases } \\
\text { alkaline phosph. }\end{array}$ & $\begin{array}{l}\text { serum hydrolases } \\
\text { alkaline phosph. } \\
\text { fibroblast cult. }\end{array}$ & 0 & fibroblast cult. + & $\begin{array}{l}\text { serum hydrolases } \\
\text { alkaline phosph. }\end{array}$ \\
\hline $\begin{array}{l}\text { Clinical } \\
\text { features } \\
\text { Notes }\end{array}$ & - & $\mathrm{B}, \mathrm{C}, \mathrm{D}$ & - & $\begin{array}{l}\text { E } \\
\text { autopsy }\end{array}$ & $\mathrm{C}$ & D \\
\hline & $\begin{array}{l}\text { 7.TD } \\
\text { (Pavia) }\end{array}$ & $\begin{array}{l}\text { 8. } \mathrm{BH} \\
\text { (Denver) }\end{array}$ & $\begin{array}{l}\text { 9. AM } \\
\text { (Denver) }\end{array}$ & $\begin{array}{l}\text { 10. NN } \\
\text { (Bordeaux) }\end{array}$ & $\begin{array}{l}\text { 11. RM } \\
\text { (Pavia) }\end{array}$ & $\begin{array}{l}\text { 12.DW } \\
\text { (Denver) }\end{array}$ \\
\hline Sex & $M$ & M & $F$ & $M$ & $\mathrm{~F}$ & F \\
\hline $\begin{array}{l}\text { Age of } \\
\text { diagnosis }\end{array}$ & $4 \mathrm{~m}$ & $8 \mathrm{~m}$ & $9 \mathrm{~m}$ & 1 y $5 \mathrm{~m}$ & $1 \mathrm{y} 6 \mathrm{~m}$ & $1 \mathrm{y} 10 \mathrm{~m}$ \\
\hline $\begin{array}{l}\text { Family } \\
\text { history }\end{array}$ & $\begin{array}{l}\text { parents 1st } \\
\text { cousins }\end{array}$ & ns & $\begin{array}{l}2 \text { previous } \\
\text { miscarriages }\end{array}$ & ns & ns & ns \\
\hline Age of death & $5 \mathrm{~m}$ & 2 y $8 \mathrm{~m}$ & $3 y$ & $6 y$ & If & $2 \mathrm{y} 4 \mathrm{~m}$ \\
\hline Bith weight & $2800 \mathrm{~g}$ & $2930 \mathrm{~g}$ & $980 \mathrm{~g}$ & $2730 \mathrm{~g}$ & 0 & 0 \\
\hline Birth length & 0 & 0 & $32 \mathrm{~cm}$ & $50 \mathrm{~cm}$ & 0 & 0 \\
\hline Caryogram & $46, X Y$ & 0 & $46, X X$ & 0 & $46, \mathrm{XX}$ & 0 \\
\hline $\begin{array}{l}\text { Laboratory } \\
\text { tests }\end{array}$ & $\begin{array}{l}\text { serum hydrolases } \\
\text { alkaline phosph. } \\
\text { parathormone } \\
\text { urinary phosph. } \\
\text { urinary calcium } \\
\text { fibroblast cult. + }\end{array}$ & serum hydrolases & serum hydrolases & $\begin{array}{l}\text { serum hydrolases } \\
\text { fibroblast cult. }+\end{array}$ & $\begin{array}{l}\text { serum hydrolases } \\
\text { fibroblasts cult. }+\end{array}$ & 0 \\
\hline $\begin{array}{l}\text { Clinical } \\
\text { features } \\
\text { Notes }\end{array}$ & $\begin{array}{l}\text { C } \\
\text { autopsy }\end{array}$ & $A, B, C$ & $\mathrm{~A}, \mathrm{~B}, \mathrm{C}$ & $A, B, C, D$ & $\begin{array}{l}\mathrm{A}, \mathrm{B}, \mathrm{C}, \mathrm{D} \\
\text { liver biopsy }\end{array}$ & $\mathrm{A}, \mathrm{B}, \mathrm{C}$ \\
\hline
\end{tabular}

ns = not significant; if $=$ lost at follow-up; $0=$ not determined or not reported; $\boldsymbol{\Lambda}=$ significantly increased; $\boldsymbol{Y}=$ significantly decreased; $+=$ inclusions in fibroblasts; $A=$ mental retardation; $B=$ Hurler-like features; $C=$ hypertrophic gums; $D=$ joint stiffness; $E=$ joint laxity; $-=$ others

In eight the diagnosis was confirmed by lysosomal enzymes determinations in serum, by inclusions in cultured fibroblasts or by both tests. In four the diagnosis was based on clinical and radiographic features alone. Data on patients and families are given in Table 1.

\section{Radiographic features}

Group I consisted of seven infants (cases 1-7) in whom the diagnosis of ML II was established at birth or soon thereafter. Similar radiographic features were observed in this group. Apart from the skull bones, the skeleton was characterized by low density and an abnormal texture which gave a fibrillar or lacunar ap. pearance to the bones. Equally affected were the short and long bones, epiphyseal nuclei, metaphyses and diaphyses (Fig. 1). Bowing of the lower limbs was present in three infants (cases 1,5, 6) and fractures of both tibias in one. The metaphyses had a cupped shape with failure of submetaphyseal remodeling. These abnormalities were observed in the proximal humerus, distal radius and ulna, proximal tibia and the distal tibia and fibula; however, they were unevenly distributed among the various cases and within each individual case. A radiotransparent horizontal band was occasionally observed in some of the cupped metaphyses (Fig. 1). In all the cases in group I, the shaft of the long bones had a poorly defined contour or a contour with a double outline image, resembling periosteal apposition. The double outline (cloaking) involved either the entire shaft or was segmental. Stippling of the tarsal bones was apparent in three cases (cases 3 , 5,7 ), absent in three, while in one X-rays of the feet were not available. Previously unreported features were observed in two newborns (cases 1 and 2), who presented with marked shortening and increased thickness of the proximal segment of both the upper and lower limbs (Fig. 2). However the deformity of these bones did not differ in quality from the other group I cases, namely coarse trabecular texture of the cortical bone, metaphyseal cupping and diaphyseal cloaking. Moreover, radiotransparent, transverse lines were present in the metaphyses. 

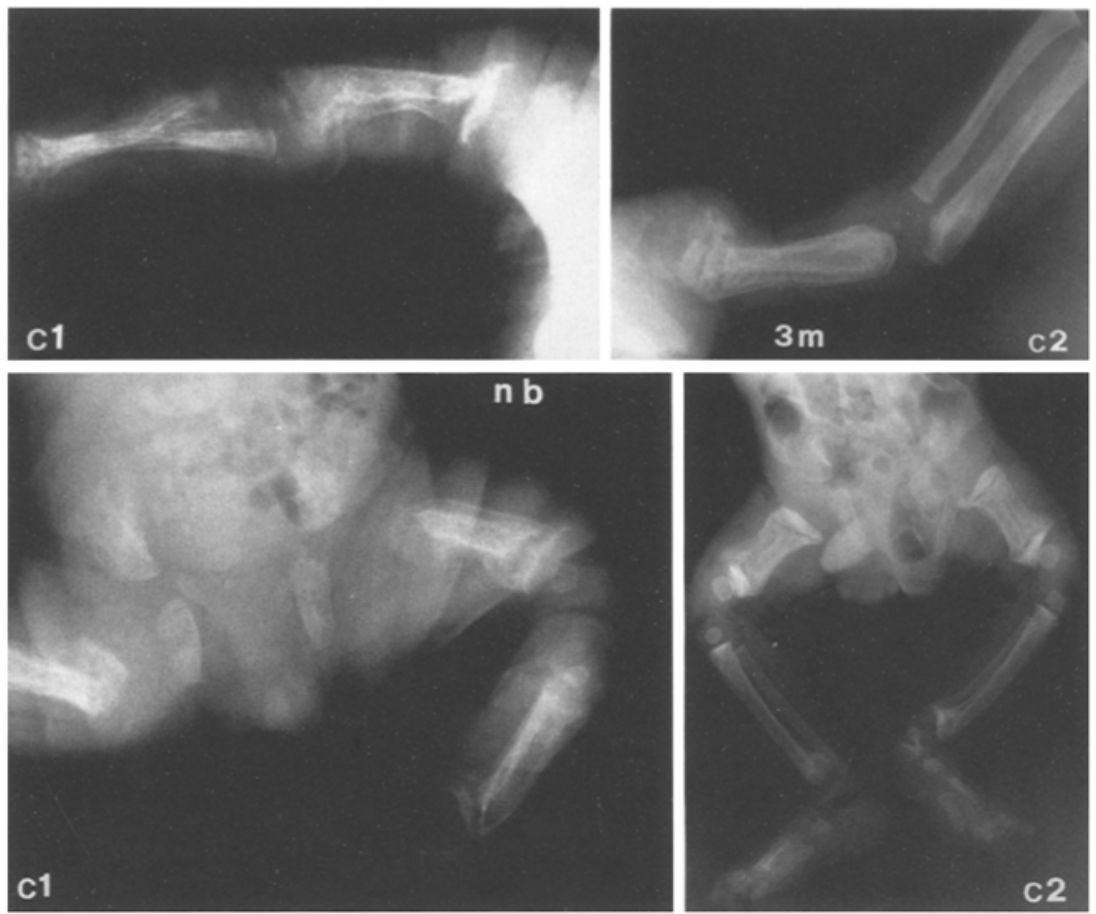

Fig. 2. Cases 1 and 2. Shortening and thickening of the proximal segment of the limbs in cases 1 and 2; the double outline image of the shaft is here very enhanced. Metaphyses are abnormally large, cupped and the radiotransparent, transverse band is a constant feature. Femora of case 2 present a dense mass of calcified material between the radiotransparent band and the epiphysis. Other aspects include osteopenia and coarse fibrillar texture of the bone in case 1
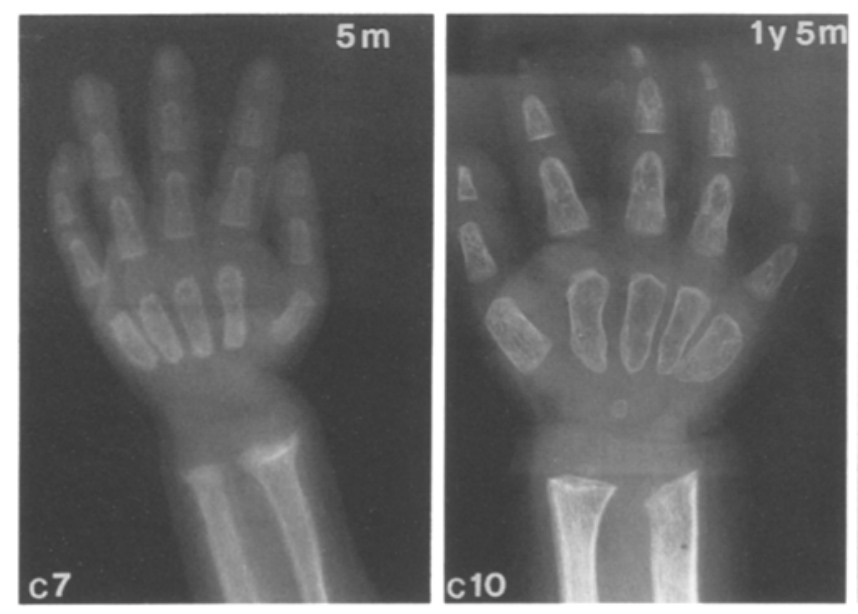

Deformities of the hand bones were also present with cone shaped proximal ends of the metacarpals and bullet-shaped and hypoplastic distal phalanges. These were less striking than in the older patients (Fig. 3, C7).

Other bone deformities observed in these patients and already described in the medical literature are summarized in Table 2.

Further assessment of the evolution of the radiographic abnormalities was not possible since five of the cases died early in life and the other two were lost to follow-up.

Five children (cases 8-12) were studied in whom bone abnormalities were first observed between the ages of eight months and twenty-two months (group II). In these cases we do not know whether bone changes had been present at birth or not. Neither generalized osteopenia nor cloaking of long bones was observed in any of these cases, though the tubular bones in both the upper and lower limbs were markedly shortened. Shaft thickness, on the other hand, was within normal limits for age. The cortices were thin and the medullary canal was enlarged.

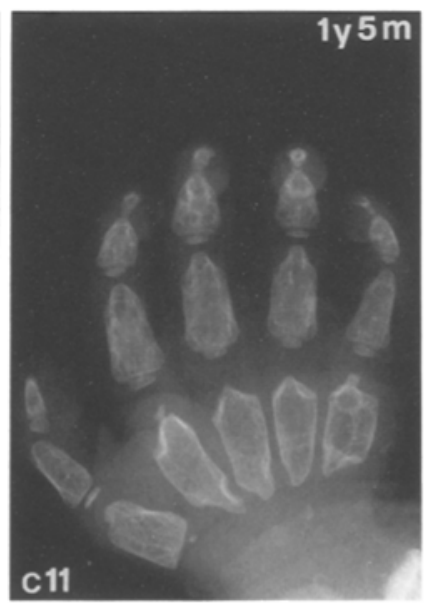

Fig. 3. Case 7. Coned-end metacarpals, bullet-shaped and hypoplastic distal phalanges. Cases 10 and 11. Abnormal slope of the distal ulnar metaphysis; short metacarpals with rectangular shape and coned ends. Proximal and middle phalanges are shortened and bullet-shaped; distal phalanges are severely hypoplastic. Absence of the cortex and coarse lacunar texture of the bone
The most obvious abnormalities were in the metaphyses: true cupping was rare but was present in both the distal fibular metaphyses of case 11 (Fig.4). Otherwise, the metaphyses were enlarged and abnormally sloped. This finding was most frequently observed in the distal ulna. Absence of submetaphyseal remodelling was the most constant feature. Stippling of the tarsus was observed in case 9. Other features including kyphosis and hypoplasia of the upper vertebral plates at the apex of kyphosis (Fig. 5), sclerosis of the base of the skull, varus deformity in the proximal humerus, dysplasia of the scapula and clavicle, flaring of the iliac wings with supracetabular constriction, valgus of the proximal femora and oar-shaped ribs with enlargement of the lateral and anterior part are summarized in Table 2.

Abnormalities of hand and foot bones were constantly observed in group II. The metacarpals and metatarsals were shortened and rectangular in shape, with coned proximal ends. The proximal and middle phalanges were shortened and bulletshaped, while the distal phalanges were markedly hypoplastic. 
Table 2. I-cell disease - X-rays features

\begin{tabular}{|c|c|c|c|c|c|c|c|c|c|c|c|c|c|}
\hline & & 1. NN & 2. BS & 3. $\mathrm{CF}$ & 4. NV & 5.CF & $6 . \mathrm{SZ}$ & 7.TD & 8. $\mathrm{BH}$ & 9. AM & 10. NN & 11. RM & 12. DW \\
\hline & Generalized osteopenia & + & $+/-$ & + & + & + & + & + & - & 0 & - & - & 0 \\
\hline & Stippling & 0 & - & + & - & + & - & + & - & + & - & - & - \\
\hline & Sclerosis of the skull base & 0 & + & + & 0 & $+1-$ & - & + & + & + & + & + & + \\
\hline \multirow[t]{2}{*}{ Skull } & $\begin{array}{l}\text { Other abnormalities of the } \\
\text { vault and facial bones }\end{array}$ & 0 & - & - & 0 & 0 & - & - & + & - & + & + & - \\
\hline & Kyphosis & 0 & + & - & 0 & + & + & + & + & 0 & + & $+1-$ & + \\
\hline \multirow[t]{2}{*}{ Spine } & Vertebral bodies abnormalities & 0 & - & + & 0 & + & + & + & + & 0 & + & + & + \\
\hline & Flared iliac wings & + & + & + & + & + & $+1-$ & + & + & + & + & + & + \\
\hline \multirow[t]{4}{*}{ Pelvis } & Supra-acetabular constriction & + & - & - & $+1-$ & + & - & + & + & + & + & + & - \\
\hline & Hip displasia or dislocation & 0 & 0 & - & - & + & - & - & + & + & + & + & - \\
\hline & Fracture or bowing & + & - & + & - & + & + & - & - & - & - & - & - \\
\hline & Coarse trabecular pattern & + & $+1-$ & + & + & + & + & + & $+1-$ & 0 & - & - & - \\
\hline \multirow[t]{5}{*}{$\begin{array}{l}\text { Long } \\
\text { bones }\end{array}$} & $\begin{array}{l}\text { Sub-periosteal remodeling } \\
\text { (cloaking) }\end{array}$ & + & + & + & + & + & + & + & - & - & - & - & - \\
\hline & $\begin{array}{l}\text { Cupping and failure of } \\
\text { metaphyseal remodelling }\end{array}$ & + & + & + & + & + & + & + & - & - & - & + & - \\
\hline & $\begin{array}{l}\text { Radiotransparent, transverse } \\
\text { metaphyseal bands }\end{array}$ & + & + & + & + & + & + & + & - & - & - & - & - \\
\hline & Late bone age & - & + & + & 0 & 0 & 0 & + & + & + & + & + & + \\
\hline & Coarse trabecular pattern & 0 & - & + & 0 & 0 & 0 & + & + & - & + & + & + \\
\hline \multirow[t]{4}{*}{$\begin{array}{l}\text { Hands and } \\
\text { feet }\end{array}$} & $\begin{array}{l}\text { Abnormalities of metacarpals } \\
\text { and metatarsals }\end{array}$ & 0 & $+1-$ & $+1-$ & 0 & 0 & 0 & $+1-$ & + & $+1-$ & + & + & + \\
\hline & Coning of phalanges & 0 & $+1-$ & $+1-$ & 0 & 0 & 0 & $+1-$ & + & 0 & + & + & + \\
\hline & Other abnormalities of phalanges & 0 & - & - & 0 & 0 & 0 & + & - & 0 & - & - & - \\
\hline & $\begin{array}{l}\text { Abnormalities of shape and } \\
\text { volume }\end{array}$ & + & + & + & + & + & + & + & + & + & + & + & + \\
\hline \multirow[t]{4}{*}{ Ribs } & $\begin{array}{l}\text { Anterior arches enlarged } \\
\text { Unusual features: }\end{array}$ & + & + & + & + & + & - & + & - & + & + & + & + \\
\hline & $\begin{array}{l}\text { Severe shortening and dysplasia } \\
\text { of the limbs segments }\end{array}$ & + & + & - & + & + & + & + & - & - & + & + & - \\
\hline & Coarse trabecular pattern & + & 0 & + & + & + & + & + & - & - & - & - & - \\
\hline & Dysplastic gleno-humeral joints & + & + & + & + & + & + & + & + & + & + & + & + \\
\hline
\end{tabular}

+ present $+1-$ mild; - absent; 0 not investigated
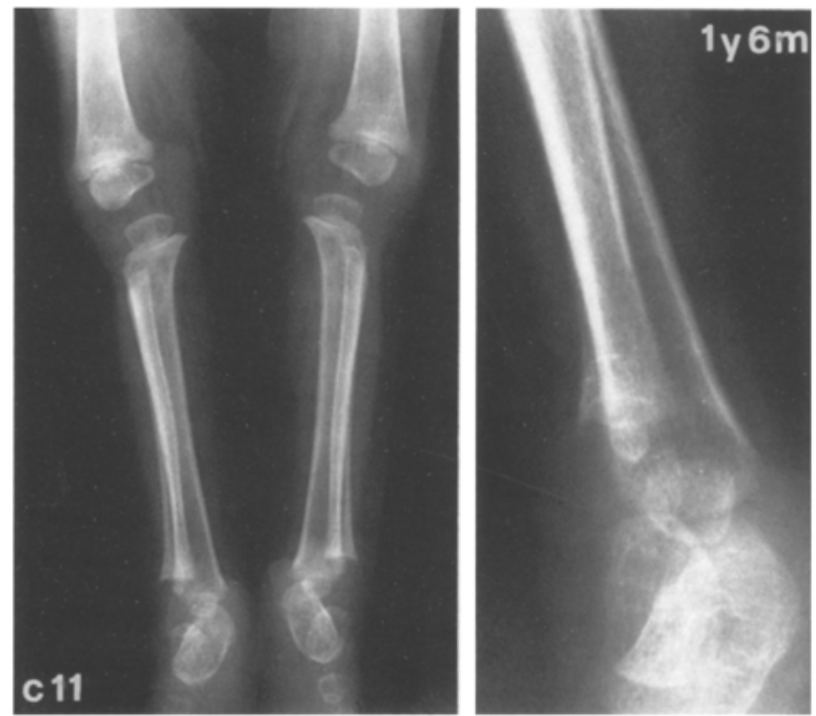

Fig.4. Case 11. Slope of femoral and tibial metaphyses, Cupping of the distal fibular metaphyses
The cortex was inapparent in these bones and their texture was fibrillar or lacunar (Fig. 3, C10-C11).

\section{Pathological features}

Bone specimens for histological study were obtained from the autopsy of cases 4 and 7 . The same abnormalities were observed in all the tubular bones examined.

The cortex consisted of lamellar bone which had undergone intense resorption, with wide lacunae filled with well vascularized connective tissue or haemopoietic marrow. In the outer part of the diaphysis, the bone was more rarefied with thin lamellae running parallel to the periosteum which consisted of several layers of fibrous tissue. Whereas subperiosteal apposition was scanty, subperiosteal bone remodeling was very active; many osteoclasts were observed and areas of osteoblastic apposition covered most of the trabecular surfaces (Fig. 6).

The growth plate cartilages were thick, with an abnormally high hypertrophic cell layer. Intercolumnar septa were not calcified (Fig. 7a) and metaphyseal vascular invasion was effected by large connective buds (Fig. $7 \mathrm{~b}$ ). The architecture of the me- 

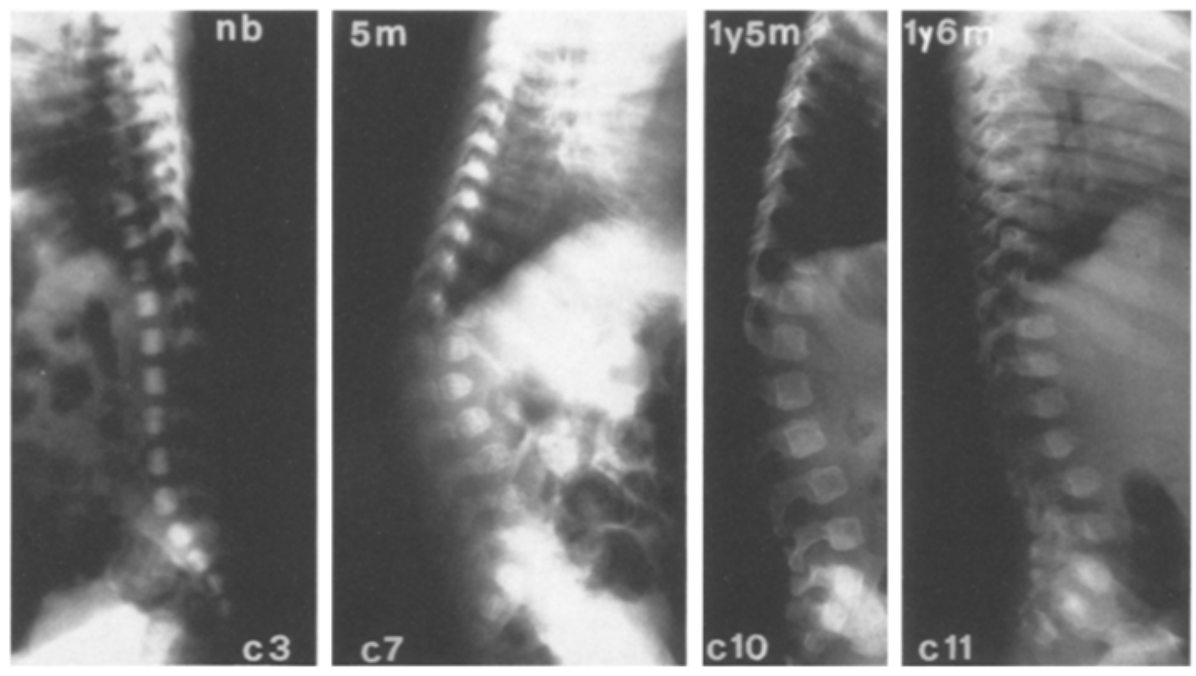

Fig.5. Cases 3, 7, 10 and 11. Features of the spine at various ages; sclerosis and abnormally high vertebral bodies at birth (C3); kyphosis and hypoplasia of the upper vertebral plates at the apex of kyphosis at later ages $(\mathrm{C} 7, \mathrm{C10}, \mathrm{C} 11)$; enlargement of the ribs (C11)

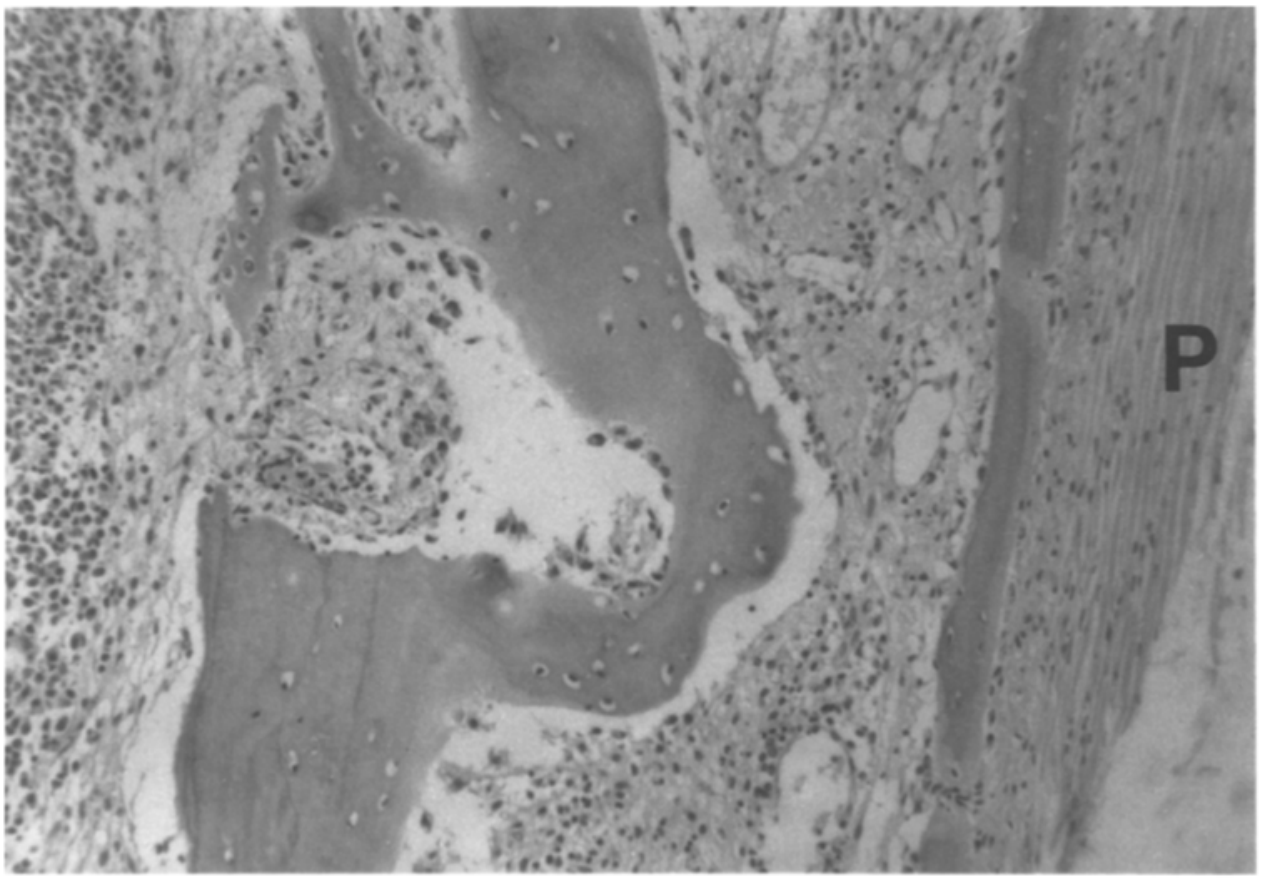

Fig. 6. Tibial diaphysis, case 7. Haematoxylin-eosin $(224 \times)$. Enhanced subperiosteal remodeling $(\mathrm{P}=$ periosteum)

taphyses was deeply subverted : bone was laid down in a disorderly fashion and no trabeculae with a cartilage core were observed. The bone was incompletely calcified and thick osteoid seams were present on the border of the trabeculae. These features strongly resembled those observed in rickets.

Secondary metaphyseal trabeculae had suffered intense remodeling and were surrounded by several layers of fibroblasts (Fig. 8). Both enhanced remodeling and para-trabecular fibrosis were also observed in epiphyseal nuclei and short bones (e.g. the vertebrae).

\section{Discussion}

The skeletal abnormalities of I-cell disease diagnosed in the neonate differ from those seen at a later age $[8,9,14]$. When I-cell disease is diagnosed for the first time at a later age it is not known whether or not radiographic abnormalities existed at birth. It seems unlikely they could have been similar to the neonatal cases of I-cell disease since skeletal involvement in the latter is of such gravity that it could hardly have been missed at birth. Moreover, the neonatal condition has a very unfavorable course and the babies die very soon thereafter. Some radiographic features in the older age group, particularly metaphyseal abnormalities, resembled those seen in the neonatal cases. Case 11, for example, revealed cupping of the distal fibular metaphyses similar to that observed in the earlier age group. The shortening of the tubular bones and failure of metaphyseal remodelling in group II pa- 


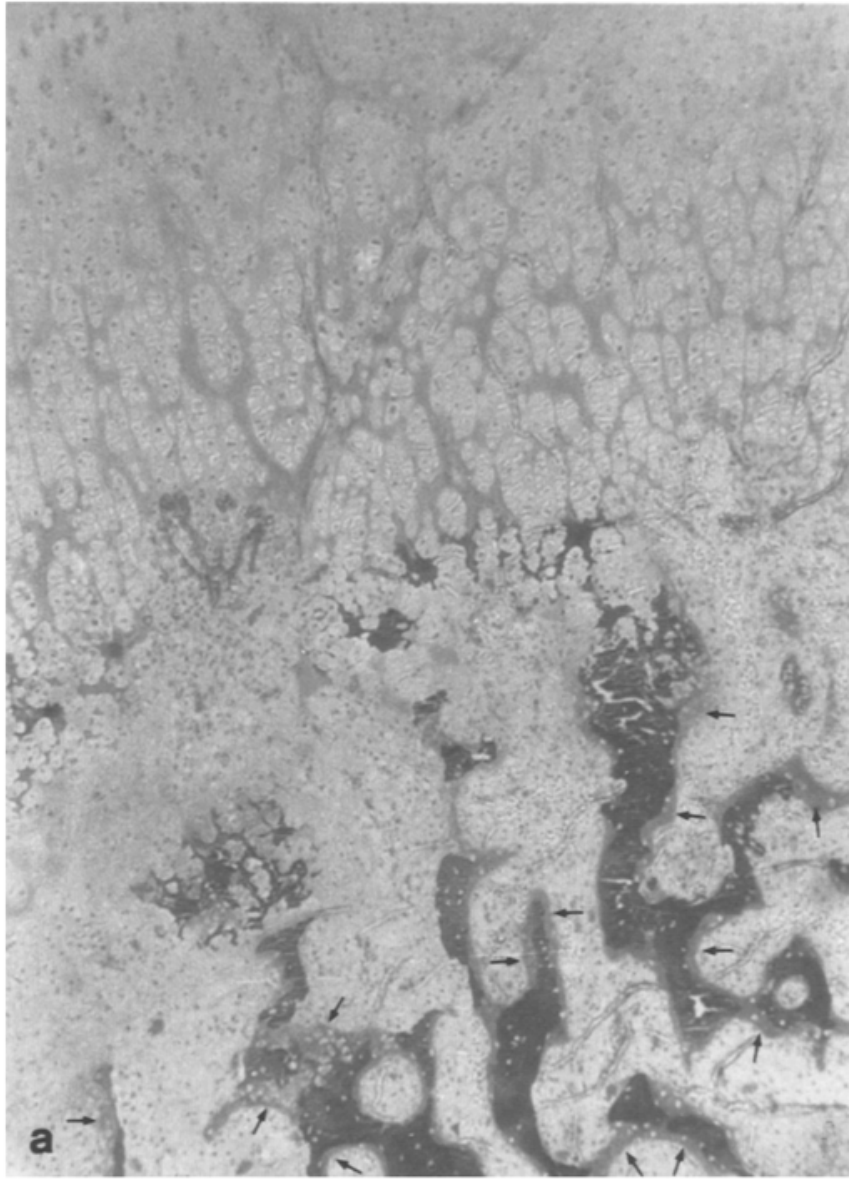

tients may also arise from a defective growth plate cartilage mechanism.

The differences observed between the two groups may be accounted for by two different hypotheses:

1. differing expressions of the same underlying disease, in some cases the enzyme defect becoming manifest early in fetal life resulting in more serious lesions of the viscera and bones.

\section{2. differing enzymatic defects resulting in different} clinical features.

It has been noted by others $[2,6,9,12,15]$ that some of the radiographic features of dysostosis multiplex strongly resemble rickets or osteomalacia. No consequences have been drawn from this observation however, and no attempt has been made to correlate the radiographic signs with the pathological nature of the bone lesions. The histological study of the bones in cases 4 and 7 would appear to explain this observation, since the inhibition of cartilage calcification and the pathological pattern of both growth plate cartilage and metaphyseal organisation are the same as in rickets. Other radiographic signs, namely,

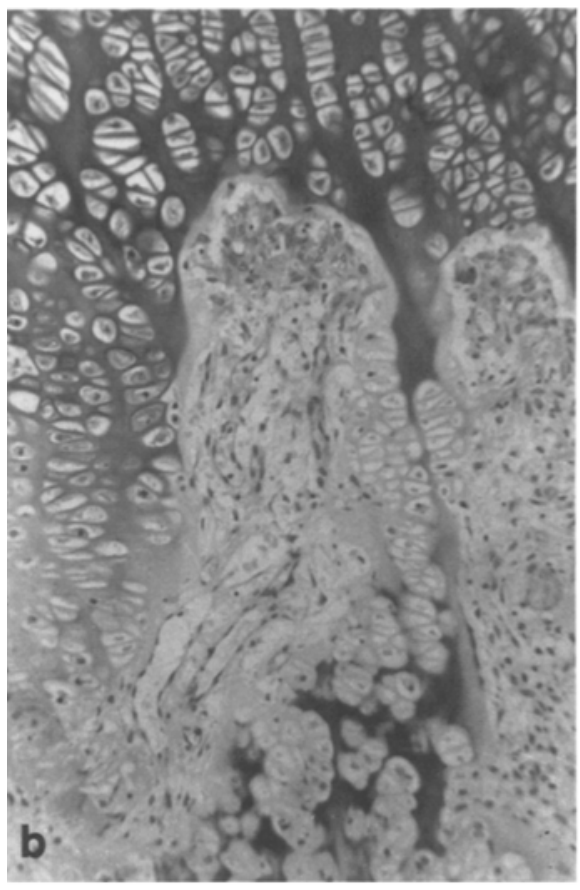

Fig. 7a, b. Proximal growth plate of the tibia, case 7. a VonKossaneutral red $(35 x)$. The hypertrophic cell layer of the growth plate cartilage is abnormally high and intercolumnar septa are not calcified. Wide osteoid beams are present on metaphyseal trabeculae (arrows). b Haematoxylin-eosin $(217 \times)$. Irregular, ricket-like pattern of vascular invasion of the growth plate cartilage

osteopenia and diaphyseal cloaking, are due to increased remodelling of the bone; in this context cloaking is the result of intense subperiosteal resorption rather than periosteal apposition. Bowing of tubular bones and fractures are secondary to bone mass loss. These signs and the presence of paratrabecular fibrosis suggest hyperparathyroidism, which was confirmed by the high levels of parathormone in one of the autoptic cases in this series. The etiology of the hyperparathyroidism is uncertain.

Very few histological studies of the bones in I-cell disease have been carried out. Martin et al. [13] describe vacuolated fibroblasts and chondrocytes and a marked disturbance of endochondral ossification; however, in their only illustration of the growth plate, irregular vascular invasion of the cartilage and abnormalities in metaphyseal organisation are clearly evident.

In the study by Babcock et al. [1] wider and denser zones of provisional calcification were observed in the tubular bones: this is certainly an early lesion of growth plate cartilage since the study was carried out in a 19 week fetus. There is, however, no discrepancy between this observation and the pathological features of our group I cases, because even in experi- 


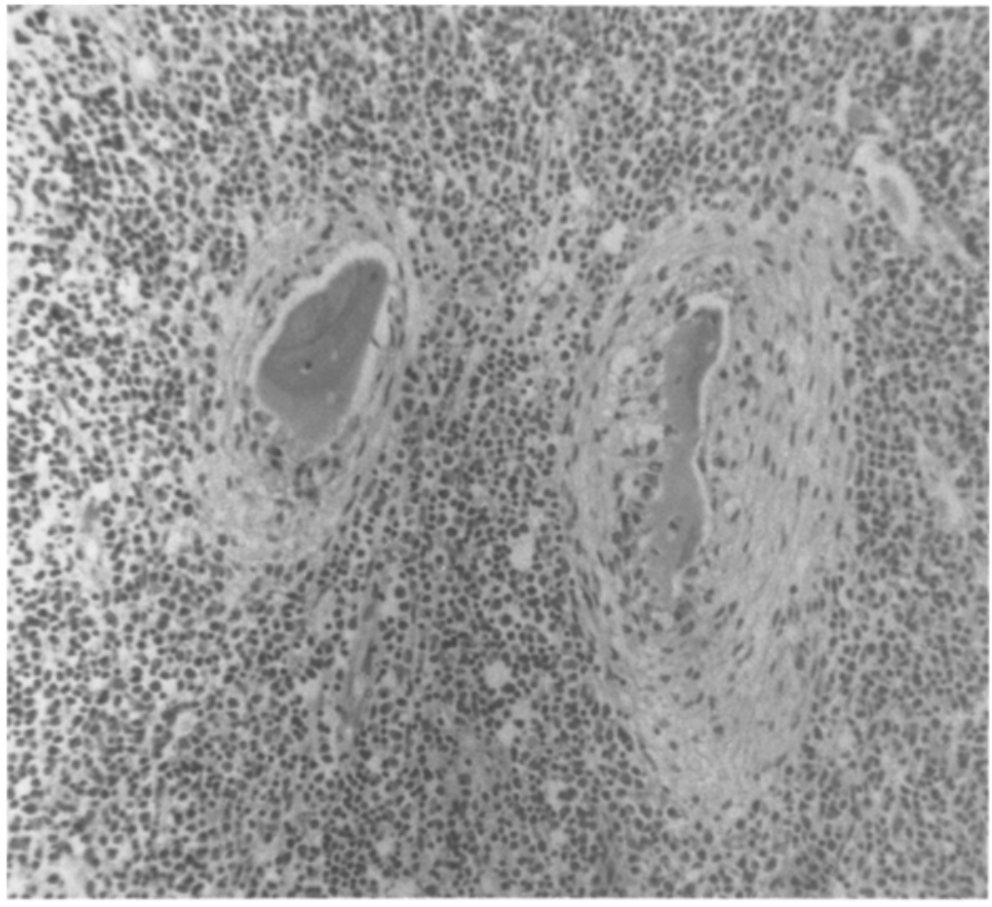

Fig. 8. Tibial metaphysis, case 7. Haematoxylin$\operatorname{eosin}(239 \times)$. Metaphyseal trabeculae have undergone extensive remodeling and are surrounded by several layers of fibrous tissue (paratrabecular fibrosis as in hyperparathyroidism) ments with such calcification inhibitors as ethane-1hydroxy-1,1-diphosphonate (EHDP) and dichloromethylene diphosphonate $\left(\mathrm{Cl}_{2} \mathrm{MDP}\right)$ a denser provisional calcification zone is observed in the earlier stages of drug administration, followed later by complete inhibition of intercolumnar septa calcification and cartilage vascular invasion [13].

These observations give a clue to the interpretation of the radiotransparent, transverse lines in the metaphyses of group I cases. In the more severely affected newborns (cases 1 and 2) the organisation of the growth plate cartilage has been subverted by a very early lesion, which interfered with the growth in length of the bone. The dense mass of calcified material between the radiotransparent line and the epiphysis should represent the zone of provisional calcification. Explanation of the severe involvement of the proximal bones of the limbs, coexisting with milder lesions of the distal segments remains speculative, such alterations might be expected to occur if the following conditions are satisfied:

- early lesion of the cartilage model of the bone

- factors operating discontinuously during fetal life

- enhanced susceptibility to damage of the cartilage model in some phases of development.

The fetal osseous malformations produced by maternal thalidomide ingestion during pregnancy are ex- plainable on a similar basis. Current hypotheses about dysostosis multiplex in I-cell disease posit a primary chondrocyte and bone cell lesion similar to visceral lesions $[7,10,13]$ but fail to provide a satisfactory explanation for the pathological rickets-like features and hyperparathyroidism observed in the bones.

It has been stated that I-cell disease is not associated with phosphorus/calcium metabolism abnormalities $[9,12]$; however, this has not been throughly investigated. Our findings, on the contrary suggest that the mechanisms of orderly calcium deposition are impaired. It is possible that, rather than resulting from a primary disorder of calcium metabolism, the bone lesions are mediated by vitamin $\mathrm{D}$ and parathormone abnormalities, which are secondary to damage to such viscera as the kidney or liver.

This study confirms the observation that I-cell disease presents clinically at two separate times of infancy, either in the neonatal period or after six to twelve months of age. The radiographic abnormalities found in older children are typical of dysostosis multiplex, whereas those seen in the neonatal cases reflect a more severe disturbance in bone development and growth. Analysis of the osseous histopathology in our autopsy cases provided an explanation for the radiographic abnormalities observed, particularly in the neonatal cases.

Acknowledgements. The authors thank Dr. Meier, chief of the Pathological Department, St.Elisabethen-Krankenhaus, Ravensburg, FRG, for the pathological material of case 4 . 


\section{References}

1. Babcock DS, Bove KE, Hug G, Dignan PSJ, Soukup S, Warren WS (1986) Fetal Mucolipidosis II (I-cell disease): radiologic and pathological correlation. Pediatr Radiol 16:32

2. Baggio P (1978) I-cell disease. Mucolipidosi II o sialidosi. Minerva Pediatr $30: 865$

3. Bianchi E, Beluffi G, Pedroni E (1975) Su di un caso di "I-cell disease". Minerva Pediatr 27: 1694

4. Blank E, Linder D (1974) I-cell disease (Mucolipidosis II): a lysosomopathy. Pediatrics 54: 797

5. Capotorti L, Jannaccone G, Ceccamea A, Colloridi V, Nardi F (1975) La malattia delle cellule con inclusioni (I-cell disease). Studio clinico-radiologico, anatomo-patologico e biochimico di 3 casi. Minerva Pediatr 27: 483

6. Cipolloni C, Boldrini A, Donti E, Maiorana A, Coppa GV (1980) Neonatal mucolipidosis II (I-cell disease): clinical radiological and biochemical studies in a case. Helv Paediatr Acta 35: 85

7. Gilbert EF, Dawson G, Zu Rhein GM, Opitz JM, Spranger JW (1973) I-cell disease, Mucolipidosis II. Histochemical, ultrastructural and biochemical observations in four cases. $\mathrm{Z}$ Kinderheilkd 114: 259

8. Jonnard A, Bost M, Pont J, Dieterlen M, Frappat P, Beaudoing A (1974) La Mucolipidose type II. Etude de deux observations familiales. Aspects cliniques et biochimiques. Pediatrie 29: 825

9. Lemaitre L, Remy T, Farriaux JP, Dhondt JL, Walbaum R (1978) Radiological signs of Mucolipidosis II or I-cell disease. Pediatr Radiol 7:97

10. Leroy JG, Martin JJ (1975) Mucolipidosis II (I-cell disease): present status of knowledge. Birth Defects 11:283

11. Leroy JG, Spranger TW, Feingold M, Opitz JM, Crocker AC (1971) I-cell disease: a clinical picture. J Pediatr 79: 360

12. Maroteaux P, Hors-Cayla MC, Pont J (1970) La Mucolipidose de type II. Presse Med 78: 179
13. Martin JJ, Leroy JG, Farriaux JP, Fontaine G, Desnick RJ, Cabello A (1975) I-cell disease (Mucolipidosis II). A report on its pathology. Acta Neuropathol (Berl) 33: 285

14. Montis de G, Garnier P, Thomassin N, Job JC, Rossier A (1972) La Mucolipidose type II (maladie des cellules a inclusions). Etude d'un cas et revue de la litterature. Ann Pediatr 19 369

15. Patriquin HB, Kaplan P, Kind HP, Giedion A (1977) Neonatal Mucolipidosis II (I-cell disease): clinical and radiological features in three cases. AJR 129: 37

16. Schenk R, Merz WA, Muhlbauer R, Russel RGG, Fleisch H (1973) Effect of Ethane-1-Hydroxy-1,1-Diphosphonate (EHDP) and Dichloromethylene Diphosphonate ( $\left.\mathrm{Cl}_{2} \mathrm{MDP}\right)$ on the calcification and resorption of cartilage and bone in the tibial epiphysis and metaphysis of rats. Calcif Tissue Res 11: 196

17. Spritz RA, Doughty RA, Spackman TJ, Murnane MJ, Coates PM, Koldovky O, Zackai EH (1978) Neonatal presentation of I-cell disease. J Pediatr 93: 954

18. Taber P, Gyepes MT, Philippard M, Ling S (1975) Roentgenographic manifestations of Leroy's I-cell disease. AJR 118: 213

19. Terashima Y, Tsuda K, Isomura S, Sugiura Y, Nogami H (1975) I-cell disease. Am J Dis Child 123: 1083

20. Whelan DT, Chang PL, Cockshott PW (1983) Mucolipidosis II. The clinical, radiological and biochemical features in three cases. Clin Genet 24: 80

Accepted: 26 April 1988

Dr, U.E. Pazzaglia

Clinica Ortopedica dell'Università di Pavia

Via Taramelli

I-27100 Pavia

Italy

\section{Literature in pediatric radiology (continued from p.394)}

Sturge-Weber syndrome: a study of cerebral glucose utilization with positron emission tomography. Chugani, H. T. et al. (Div. of Ped. Neurol., Room MDCC 22-464, UCLA School of Med., Los Angeles, CA 90024 , USA) 114, 244 (1989)

Computed tomography scanning of the liver to determine efficacy of iron chelation therapy in thalassemia major. Olivieri, N. F. et al. (Freedman, M. H., The Hosp. for Sick Schildren, 555 Univ. Ave., Toronto, Ontario, Canada M5G 1X8) 114, 427 (1989)

Journal of Pediatric Surgery (New York)

Congenital metastatic cervical teratoma: diagnostic and management considerations. Touran, T. et al. (Applebaum, H., Div, of Ped. Surg., Kaiser Permanente Med. Center, 1526 N Edgemont St, Los Angeles, CA 90027, USA) 24, 21 (1989)

Pancreas divisum, pancreatic pseudocyst, and choledochal cyst in an 8-year-old child. Tuggle, D. W., Smith, E. I. (PO Box 26307, Oklahoma City, OK 73126, USA) 24, 52 (1989)

Microcolon in the absence of small bowel obstruction in the newborn. Le onidas, J. C. (Dept. of Rad., Schneider Children's Hosp., Long Island Jewish Med. Center, New Hyde Park, NY 11042, USA) 24, 180 (1989)

Primary disorders of the lymphatic vessels - a unified concept. Levine, C., Dept. of Rad., DC 069.00, Univ., Columbia Hosp. and Clinics, One Hosp. Dr, Columbia, MO 65212, USA) 24, 233 (1989)

Gastroesophageal dysfunction in Cornelia de Lange syndrome. Cates, $\mathbf{M}$ et al. (Grosfeld, J. L., J. W. Riley Hosp. for Children (K21), 702 Barnhill Dr, Indianapolis, IN 46223, USA) 24, 248 (1989)

Bilateral hydrothorax complicating central venous catheterization in a child: case report. Ross, Jr., P., Seashore, J. H. (Seashore, J. H., Dept. of
Surgery, Yale Univ. School of Med., 33 Cedar St, New Haven, CT 06510 , USA) 24, 263 (1989)

Adrenocortical tumors in childhood: a report of four cases. Morales, L et al. (Serv. de Cirugia Péd., Hosp. Clinico y Privincial, Villarroel 170, 08036 Barcelona, Spain) 24, 276 (1989)

Familial achalasia in two siblings: significance of possible hereditary role. Tryphus, M. R. et al. (Davis, M., Dept. of Rad., The Univ. Hosp., Albuquerque, NM 87131, USA) 24, 292 (1989)

Fetus in fetu: a case report and review of the literature. Eng, H-L. et al. (Chen, W-J., Dept. of Path., Med. Center, Chang Gung Memorial Hosp., Kaohsiung, Taiwan, Rep. of China) 24, 296 (1989)

Adrenal hemorrhage with incomplete rotation of the colon leading to early duodenal obstruction: case report and review of the literature. Cheves, H. et al. (Rhea, W. G., Dept. of Surgery, Memorial Hosp., 701 Grove Rd, Greenville, SC 29605, USA) 24, 300 (1989)

Ductus arteriosus aneurysm: an unusual mediastinal mass. Siragusa, R. J., Cumming, W. A. (Dept. of Rad., Halifax Med. Center, Daytona Beach, FL 32014, USA) 24, 309 (1989)

Journal of Urology (Baltimore)

Ectopic vas deferens, imperforate anus and hypospadias: a new triad. Hicks, C. M. et al. (Urol. Serv., Walter Reed Army Med. Center, Washington, D. C. 20307-5001, USA) 141, 586 (1989)

Pediatrics (Evanston IL)

Acute profound dystonia in infants with glutaric acidemia. Bergman; I. et al. (Children's Hosp., One Children's Place, 3705 Fifth Ave at DeSoto St, Pittsburgh, PA 15213-3417, USA) 83, 228 (1989) 